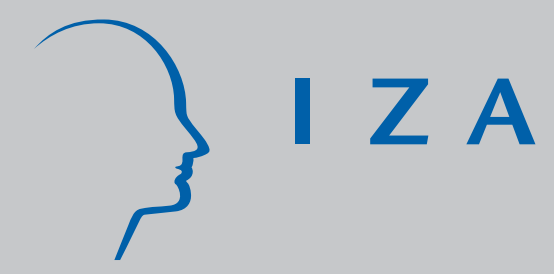

IZADP No. 1912

Do Home Computers Improve Educational

Outcomes? Evidence from Matched Current

Population Surveys and the National

Longitudinal Survey of Youth 1997

Daniel O. Beltran

Kuntal K. Das

Robert W. Fairlie

J anuary 2006 


\title{
Do Home Computers Improve Educational Outcomes? Evidence from Matched Current Population Surveys and the National Longitudinal Survey of Youth 1997
}

\author{
Daniel O. Beltran \\ University of California, Santa Cruz \\ Kuntal K. Das \\ University of California, Santa Cruz \\ Robert W. Fairlie \\ University of California, Santa Cruz, National Poverty Center \\ and IZA Bonn
}

Discussion Paper No. 1912

January 2006

IZA

P.O. Box 7240

53072 Bonn

Germany

Phone: +49-228-3894-0

Fax: +49-228-3894-180

Email: iza@iza.org

\begin{abstract}
Any opinions expressed here are those of the author(s) and not those of the institute. Research disseminated by IZA may include views on policy, but the institute itself takes no institutional policy positions.
\end{abstract}

The Institute for the Study of Labor (IZA) in Bonn is a local and virtual international research center and a place of communication between science, politics and business. IZA is an independent nonprofit company supported by Deutsche Post World Net. The center is associated with the University of Bonn and offers a stimulating research environment through its research networks, research support, and visitors and doctoral programs. IZA engages in (i) original and internationally competitive research in all fields of labor economics, (ii) development of policy concepts, and (iii) dissemination of research results and concepts to the interested public.

IZA Discussion Papers often represent preliminary work and are circulated to encourage discussion. Citation of such a paper should account for its provisional character. A revised version may be available directly from the author. 


\title{
ABSTRACT \\ Do Home Computers Improve Educational Outcomes? Evidence from Matched Current Population Surveys and the National Longitudinal Survey of Youth $1997^{*}$
}

\begin{abstract}
Nearly twenty million children in the United States do not have computers in their homes. The role of home computers in the educational process, however, has drawn very little attention in the previous literature. We use panel data from the two main U.S. datasets that include recent information on computer ownership among children - the 2000-2003 CPS Computer and Internet Use Supplements (CIUS) matched to the CPS Basic Monthly Files and the National Longitudinal Survey of Youth 1997 - to explore the relationship between computer ownership and high school graduation and other educational outcomes. Teenagers who have access to home computers are 6 to 8 percentage points more likely to graduate from high school than teenagers who do not have home computers after controlling for individual, parental, and family characteristics. We generally find evidence of positive relationships between home computers and educational outcomes using several estimation strategies, including controlling for typically unobservable home environment and extracurricular activities in the NLSY97, fixed effects models, instrumental variables, future computer ownership and "pencil tests". Some of these estimation techniques, however, provide imprecise estimates. Home computers may increase high school graduation by reducing nonproductive activities, such as truancy and crime, among children in addition to making it easier to complete school assignments.
\end{abstract}

JEL Classification: $\quad 12$

Keywords: computers, educational outcomes, technology

Corresponding author:

Robert W. Fairlie

Department of Economics

Engineering 2 Building

University of California

Santa Cruz, CA 95064

USA

Email: rfairlie@ucsc.edu

\footnotetext{
* This research was funded by the William T. Grant Foundation. The views expressed here are those of the authors and not necessarily those of the William T. Grant Foundation. We would like to thank Josh Angrist, Duncan Chaplin, Thomas Luschei, and seminar participants at the W.T. Grant Foundation Economics and Technology workshop, University of North Carolina, CJTC workshop and Stanford University.
} 


\section{Introduction}

The impact of computers in schools has been hotly debated by policy makers, academics, and the media. Meta-analyses and literature reviews find widely varying estimates of the effects of computer use in schools on academic performance (see Noll, et al. 2000 and Kirkpatrick and Cuban 1998 for example). Recent evidence from a quasi-experiment in Israeli schools indicates no improvement in math test scores (Angrist and Lavy 2002), and evidence from a random experiment suggests that a popular language program may improve some language skills, but does not improve broader language acquisition and reading skills (Rouse and Krueger 2004). Interestingly, however, school principals and teachers overwhelmingly support the use of educational technology. In a recent national survey funded by the U.S. Department of Education, nearly all principals report that educational technology will be important for increasing student performance in the next few years, and a clear majority of teachers report that the use of technology is essential to their teaching practices (SRI 2002). Ninety-two percent of all instructional classrooms in U.S. public schools have computers with Internet access, with an average of 3.5 computers per classroom (U.S. Department of Education 2004a).

The federal government has also made the provision of computer and Internet access to school children a top priority. Spending on the E-rate program, which provides discounts to schools and libraries for the costs of telecommunications services and equipment, totaled $\$ 12.9$ billion from 1998 to 2003 (Universal Services Administration Company 2003). ${ }^{1}$ Recently, the U.S. Department of Education released the National Educational Technology Plan as part of the No Child Left Behind Policy. The plan calls for increased teacher training in technology, elearning opportunities for students, access to broadband, digital content and integrated data systems (U.S. Department of Education 2004b). Several state, local government and private

\footnotetext{
${ }^{1}$ See Puma, et al.(2000) and Goolsbee and Guryan (2005) for more details and analyses of the program. Goolsbee and Guryan (2005) find that increased Internet connections in schools resulting from the E-rate program do not have a measurable effect on student test scores.
} 
programs also provide laptop computers to schoolchildren. ${ }^{2}$ The most ambitious program provides every $7^{\text {th }}$ and $8^{\text {th }}$ grade student and their teachers with a laptop computer in Maine, totaling over 34,000 students and 3,000 teachers at a cost of nearly $\$ 40$ million.

The role of home computers in the educational process, however, has drawn very little attention in the literature. The lack of attention is surprising because of its potential implications for disparities in access to technology or the so-called Digital Divide. Although computers are universal in the classroom, nearly twenty million children, representing 26 percent of all children in the United States, do not have computers in their homes. Furthermore, there is no clear theoretical prediction regarding whether home computers are likely to have a negative or positive effect on educational outcomes. Home computers may exert a positive influence on academic performance directly through the use of educational software and indirectly by facilitating the completion of school assignments and learning. The use of home computers may also "open doors to learning" encouraging some teenagers to stay in school (Cuban 2001 and Peck, et al. 2002), reduce crime, and alter the economic returns to completing high school. On the other hand, home computers are often criticized for providing a distraction to children through video games and the Internet or for displacing other more active forms of learning (Giacquinta et al. 1993 and Stoll 1995), and the Internet makes it substantially easier to plagiarize and find information from non-credible sources. Therefore, it is an empirical question as to which of the two opposing forces dominates. Indeed, the few previous studies examining the relationship between home computers and educational outcomes find somewhat mixed results (Attewell and Battle 1999; Schmitt and Wadsworth 2004; Fuchs and Woessmann 2004; Fairlie 2005).

The answer to whether home computers improve educational outcomes is especially important in light of the large and persistent disparities in access to technology across racial, income and other demographic groups. For example, estimates from the 2003 Current Population

\footnotetext{
${ }^{2}$ See Stevenson (1999), Lowther, et al. (2001), Rockman, et al. (2000), Silvernail and Lane (2004), Mitchell Institute (2004) and Urban-Lurain and Zhao (2004) for example, and Keefe, et al. (2003) for a summary of numerous programs.
} 
Survey (CPS) indicate that roughly one half of all African-American and Latino children and less than half of all children living in families with incomes less than $\$ 30,000$ have access to home computers. In comparison, 85 percent of white, non-Latino children and 94 percent of children in families with incomes greater than $\$ 60,000$ have access to home computers. If home computers are an important input into the educational process then disparities in access to technology may translate into future disparities in educational and economic outcomes. ${ }^{3}$ Financial, informational and technical constraints may limit the optimal level of investment in personal computers among some families.

In this study, we provide a comprehensive non-experimental analysis of the relationship between computer ownership and high school graduation and other educational outcomes. We use panel data from the two main U.S. datasets that include recent information on computer ownership among children -- the 2000-2003 CPS Computer and Internet Use Supplements (CIUS) matched to the CPS Basic Monthly Files and the National Longitudinal Survey of Youth 1997, and employ several empirical strategies to identify causal effects. ${ }^{4}$ We find fairly consistent evidence that home computers have a strong positive relationship with high school graduation and additional educational outcomes. The estimated effects of home computers are generally similar even after controlling for detailed, and typically unobservable, measures of the home environment and extracurricular activities, instrumental variables, and fixed effects. We also do not find evidence of a strong relationship between educational outcomes and future computer ownership, cable television or the presence of a dictionary at home, which may be correlated with unobservables but cannot or are unlikely to have causal effects. The estimates also suggest that home computers may increase high school graduation partly by reducing nonproductive activities, such as truancy and crime, among children.

\footnotetext{
${ }^{3}$ See Noll, et al. (2000) and Crandall (2000) for an example of the academic debate over the importance of the digital divide.

${ }^{4}$ Although the CPS CIUS is a cross-sectional dataset, it can be matched to monthly CPS files to create oneyear panel data.
} 


\section{Previous Research}

Only a few previous studies examine the effects of home computers on educational outcomes. Using the 1988 National Educational Longitudinal Survey (NELS), Attewell and Battle (1999) provide evidence that test scores and grades are positively related to home computer use even after controlling for differences in several demographic and individual characteristics including typically unobservable characteristics of the educational environment in the household. ${ }^{5}$ They find that students with home computers score 3 to 5 percent higher on tests than students without home computers. Schmitt and Wadsworth (2004) also provide evidence of a positive relationship between home computer ownership and subsequent academic achievement. Using the British Household Panel Survey, they find a significant positive association between home computers and performance on the British school examinations. The results are robust to the inclusion of individual, household and geographical controls, including proxies for household wealth and prior educational attainment. In contrast to these findings, Fuchs and Woessmann (2004) find a negative relationship between home computers and student achievement using the international student-level Programme for International Student Achievement (PISA) database. They find that students with home computers have significantly lower math and reading scores after controlling for student, family and school characteristics and country fixed effects.

Although these previous studies control for numerous individual, family and school characteristics, their estimates of the effects of home computers on educational outcomes may be biased due to omitted variables. In particular, if the most educationally motivated families are the ones that are the most likely to purchase computers, then a positive relationship between academic performance and home computers may simply capture the effect of unmeasurable

\footnotetext{
${ }^{5}$ They include measures of the frequency of child-parent discussions of school-related matters, parents' familiarity with the parents of their child's friends, attendance in "cultural" classes outside of school, whether the child visits science or history museums with the parent, and an index of the educational atmosphere of the home (e.g. presence of books, encyclopedias, newspapers, and place to study).
} 
motivation on academic performance. Conversely, if the least educationally motivated families (after controlling for child and family characteristics) are the ones that are more likely to purchase computers then their estimates may understate the effects of home computers.

Schmitt and Wadsworth (2004) investigate this issue by estimating regression models that include future computer ownership in addition to previous computer ownership. If future computer ownership has a positive effect on achievement then one might suspect that computer ownership proxies for an unobserved factor, such as educational motivation. They find statistically insignificant coefficients on these variables, whereas the coefficient on past computer ownership generally remains positive and statistically significant in their regression models, suggesting that home computers may be an important factor in the educational production function.

Fairlie (2005) addresses the endogeneity issue by estimating instrumental variable models. The question of whether access to home computers increases the likelihood of school enrollment among teenagers who have not graduated from high school is analyzed using data from the 2001 CPS CIUS. ${ }^{6}$ The focus on school enrollment is useful because the effects of access to home computers on this outcome may differ from those on grades, test scores, and other direct measures of academic performance. A comparison of school enrollment rates reveals that 95.2 percent of children who have home computers are enrolled in school, whereas only 85.4 percent of children who do not have home computers are enrolled in school. Controlling for family income, parental education, parental occupation and other observable characteristics in probit regressions for the probability of school enrollment, the difference is 1.4 percentage points. Although the evidence is mixed on whether these probit estimates are biased, bivariate probit models for the joint probability of school enrollment and owning a home computer are also

\footnotetext{
${ }^{6}$ The analysis was limited to examining the effects of home computers on school enrollment because only the cross-sectional 2001 CPS was used.
} 
estimated and reveal larger effects (7.7 percentage points). Use of computers and the Internet by the child's mother and father are used as exclusion restrictions.

We contribute to the sparse literature on the educational impacts of home computers by using the two major U.S. panel datasets with recent information on computer ownership - the matched CPS data and the NLSY97 -- and employing several empirical strategies to identify the causal effects of home computers on high school graduation and other educational outcomes. ${ }^{7}$ The detailed panel data available in the CPS and NLSY97 allow for the estimation of specifications that include detailed home environment controls, instrumental variables, fixed effects, and future computer ownership. We explore the relationship between home computer and high school graduation, grades, school suspension and criminal activities, and present a simple theoretical model to shed light on potential mechanisms. This comprehensive approach has not been taken in the previous literature.

\section{Theory}

Before turning to the empirical results, we first present a simple theoretical model of high school graduation that illustrates the potential effects of home computers. A linear random utility model of the decision to graduate from high school is used. Define $U_{i 0}$ and $U_{i 1}$ as the $i$ th person's indirect utilities associated with not graduating from high school and graduating from high school, respectively. These indirect utilities can be expressed as:

(3.1) $U_{i 0}=\alpha_{0}+\beta_{0}{ }^{\prime} X_{i}+\gamma_{0} C_{i}+\lambda_{0} t\left(W_{i}, C_{i}\right)+\theta Y_{0}\left(Z_{i}, C_{i}\right)+\varepsilon_{i 0}$, and

(3.2) $U_{i 1}=\alpha_{1}+\beta_{1}^{\prime} X_{i}+\gamma_{1} C_{i}+\lambda_{1} t\left(W_{i}, C_{i}\right)+\theta Y_{1}\left(Z_{i}, C_{i}\right)+\varepsilon_{i 1}$,

where $X_{i}, Z_{i}$ and $W_{i}$ are individual, parental, family, geographical and school characteristics, $C_{i}$ is the presence of a home computer, $Y_{0}$ and $Y_{1}$ are expected future earnings, and $t$ is the child's

\footnotetext{
${ }^{7}$ A few studies examine the educational effects of the provision of one-to-one laptops to schoolchildren (Stevenson 1999, Lowther, et al. 2001, Rockman, et al. 2000, Silvernail and Lane 2004, Mitchell Institute 2004 and Urban-Lurain and Zhao 2004). There is some evidence that laptops are associated with improved educational performance including test scores and attendance, but because the laptops are used both in school and at home it is impossible to separately identify the home impact.
} 
achievement (e.g. test score), and $\varepsilon_{i}$ is an additive error term. $X_{i}, Z_{i}$ and $W_{i}$ do not necessarily include the same characteristics. Achievement is determined by the characteristics, $W_{i}$, and the presence of computers is allowed to have different effects on the utility from the two educational choices. Expected earnings differ between graduating from high school and not graduating from high school, and are functions of the characteristics, $Z_{i}$, and home computers.

In the simple model, there are three major ways in which home computers affect educational outcomes. First, there is a direct effect of having a home computer on the utility of graduating from high school, $\gamma_{1}$. Personal computers make it easier to complete homework assignments through the use of word processors, spreadsheets, Internet browsers and other software, thus increasing the utility from completing schoolwork (Lenhart, et al. 2001). Access to a home computer may also familiarize the student with computers increasing the returns to computer use in the classroom or increasing preparation for class (Underwood, et al. 1994, Mitchell Institute 2004). Estimates reported below indicate that approximately 9 out of 10 high school students who have access to a home computer use that computer to complete school assignments. Further, 46 percent of teachers report that lack of student access to technology/Internet is a barrier to effective use of technology in the classroom (SRI 2002), and results from school laptop programs indicate very high rates of use of these computers for homework (Stevenson 1999, Mitchell Institute 2004, Urban-Lorain and Zhao 2004).

Access to home computers may have an additional effect on the utility of staying in school beyond making it easier to finish homework and complete assignments at school. In particular, the use of home computers may "open doors to learning" and doing well in school (Cuban 2001 and Peck, et al. 2002), and thus encourage some teenagers to graduate from school. The use of computers at home may also translate into more positive attitudes towards information technology potentially leading to long-term use (Selwyn 1998). Many teachers report that educational technology increases outside class time initiative among students (SRI 2002). 
Personal computers also provide utility from games, email, chat rooms, downloading music, and other non-education uses creating an opportunity cost from doing homework. The higher opportunity cost increases the utility of not graduating from high school. Computers are often criticized for providing a distraction for children through video games and the Internet or for displacing other more active forms of learning (Giacquinta, et al. 1993 and Stoll 1995). Fuchs and Woessmann (2004) find international evidence of a negative effect of home computers on test scores and suggest that it may be due to the distraction from effective learning. On the other hand, the use of computers at home, even for these non-educational uses, keeps children off the street, potentially reducing delinquency and criminal activities. These activities increase the utility from dropping out of school. The two opposing factors make it difficult to sign the effect of computers on the utility from not graduating from high school, $\gamma_{0}$.

Another way in which personal computers affect the high school graduation decision is through their effects on academic achievement. Computers could improve academic performance directly through the use of educational software and focusing time use on content. As noted above, previous research finds that home computers are associated with higher test scores (Attewell and Battle 1999 and Schmitt and Wadsworth 2004). Computers, however, may displace other more active forms of learning and decrease learning by emphasizing presentation (e.g. graphics) over content (Giacquinta, et al. 1993 and Stoll 1995). The Internet also makes it substantially easier to plagiarize and find information from non-credible sources. Therefore, the theoretical effects of computers on academic achievement, $\delta \mathrm{t} / \delta \mathrm{C}$, and thus on the utility from graduating from high school, $\lambda_{1} \delta \mathrm{t} / \delta \mathrm{C}$, is ambiguous.

Finally, home computers and the skills acquired from using them may alter the economic returns to completing high school. It is well known that information technology skills are becoming increasingly important in the labor market. The share of employment in information technology industries and occupations and the share of employees using computers and the 
Internet at work have risen dramatically over the past decade (Freeman 2002), and a large percentage of new hires are required to use computers (Holzer 1996). Computer skills may improve employment opportunities and wages, but mainly in combination with a minimal educational credential such as a high school diploma, implying that $\delta \mathrm{Y}_{1} / \delta \mathrm{C}>\delta \mathrm{Y}_{0} / \delta \mathrm{C}$. Valletta (2004) finds some evidence of an increasing positive relationship between wages and computer use by education level.

Focusing on the high school graduation decision, we assume that the individual graduates from high school if $U_{i 1}>U_{i 0}$. The probability of graduating from high school, $y_{i}=1$, is:

(3.3) $P\left(y_{i}=1\right)=P\left(U_{i 1}>U_{i 0}\right)=$

$F\left[\left(\alpha_{1}-\alpha_{0}\right)+\left(\beta_{1}-\beta_{0}\right)^{\prime} X_{i}+\left(\gamma_{1}-\gamma_{0}\right) C_{i}+\theta\left(Y_{1}\left(Z_{i}, C_{i}\right)-Y_{0}\left(Z_{i}, C_{i}\right)\right)+\left(\lambda_{1}-\lambda_{0}\right) t\left(W_{i}, C_{i}\right)\right]$

where $F$ is the cumulative distribution function of $\varepsilon_{i 1}{ }^{-} \varepsilon_{i 0}$. The model can be estimated with a logit regression by assuming that $\varepsilon_{i 1}-\varepsilon_{i 0}$ has a type I extreme value distribution. In (3.3), the separate effects of computers on the probability of graduating from high school are expressed in relative terms. Home computers have a direct effect on the graduation probability through relative utility, and indirect effects through improving achievement and altering relative earnings.

Unfortunately, identification of the separate parameters is difficult and requires $\mathrm{Z}$ and $\mathrm{W}$ to contain elements not included in X, a good measure of achievement, and the calculation of predicted earnings for both educational choices. Instead of assuming a structural form and/or applying tenuous exclusion restrictions and making distribution assumptions, we estimate the following reduced form model:

(3.4) $P\left(y_{i}=1\right)=F\left[\alpha+\beta^{\prime} \pi_{i}+\gamma C_{i}\right]$,

where $\pi$ includes all individual, parental, family and school characteristics. Although the more detailed assertions of the theoretical model cannot be tested, the total effect of home computers on high school graduation can be estimated using (3.4). The theoretical model does not provide a 
prediction regarding the sign or magnitude of the effect of home computers on high school graduation, and thus we turn to an empirical analysis.

\section{Data}

The datasets used in the analysis are the matched Computer and Internet Use Supplements (CIUS) and Monthly Basic files to the Current Population Survey (CPS) and the National Longitudinal Survey of Youth 1997 (NLSY97). The CIUS, conducted by the U.S. Census Bureau and the Bureau of Labor Statistics, is representative of the entire U.S. population and interviews approximately 50,000 households. It contains a wealth of information on computer and Internet use, including detailed data on types and location of use. The NLSY97 is a nationally representative sample of 8,984 young men and women who were between the ages of 12 and 16 on December 31, 1996. ${ }^{8}$ Survey members were interviewed annually from 1997 to 2002. The NLSY97 contains an oversample of 2,236 black and Latino youth in the same age group. The NLSY97 contains information on computer ownership and detailed information on educational outcomes, criminal activities, and individual and family characteristics.

To explore the relationship between computer ownership and subsequent high school graduation, we link CPS files over time to create longitudinal data. Households in the CPS are interviewed each month over a 4-month period. Eight months later they are re-interviewed in each month of a second 4-month period. The rotation pattern of the CPS makes it possible to match information on individuals in a CIUS who are in their first 4-month rotation period (e.g. October 2003) to information from the same month in their second 4-month rotation period (e.g. October 2004), thus creating a one-year panel for up to half of all respondents in the CIUS files. To match these data, we follow the approach taken in Madrian and Lefgren (2000).

\footnotetext{
${ }^{8}$ See Center for Human Resource Research (2003) for additional details on the NLSY97 sample.
} 


\section{Home Computers and High School Graduation}

Although access to computers in the nation's schools is universal, access to home computers is far from 100 percent among children. Estimates from the 2003 CPS indicate that slightly more than one fourth of all children in the United States do not have access to a computer at home. Among children ages 16 to 18 who have not graduated from high school, slightly more than 20 percent do not have access to a home computer (see Table 1). Levels of access to home technology are substantially lower for low income and disadvantaged minority groups (see Novak and Hoffman 1998, U.S. Department of Commerce 2002, and Fairlie 2004).

Table 1 also reports estimates of patterns of computer use among teenagers. Not surprisingly, teenagers use their home computers -- 94.6 percent of teenagers who have access to a home computer use it. Computers also appear to be useful for completing school assignments. Conditioning on computer ownership, only 81.6 percent of teenagers not enrolled in school use computers at home compared to 95.2 percent of enrolled teenagers. Among school enrollees who use home computers, 93.4 percent report using them to complete school assignments. Another interesting finding is that 71.1 percent of enrolled computer users use their computer for word processing whereas only 38.8 percent of non-enrolled computer users use their computer for word processing.

Teenagers also use home computers for many other purposes. The most common uses of home computers among teenagers are for the Internet (86.9 percent), games (72.6 percent), and email (78.2 percent). Use of home computers for graphics and design (45.0 percent) and spreadsheets or databases (22.1 percent) in addition to word processing are also fairly common. None of these uses among high school students, however, is as prevalent as using home computers to complete school assignments. Concerns that home computers are only used for non-educational purposes such as playing games, listening to music, and emailing friends, appear to be exaggerated. 
At a minimum, estimates from the 2003 CPS indicate that home computers are useful for completing school assignments. Whether these students wrote better reports or could have completed similar quality school assignments at a library, community center or school, however, is unknown. Furthermore, the prevalence of non-educational uses of home computers suggests that home computers may also provide a distraction that lessens or negates their educational impact. The first step in attempting to answer this question is to examine whether children who have access to home computers are more likely to graduate from high school than children who do not have home computers.

Table 2 reports estimates of high school graduation rates by previous computer ownership. The CPS sample includes children ages 16-18 who live with at least one parent and report finishing the $11^{\text {th }}$ and $12^{\text {th }}$ grade, but have not graduated from high school in the first survey year. Computer ownership is determined in the first survey year, and high school graduation is determined in the second survey year. ${ }^{9}$ Thus, the graduation rate that we use is defined as the percent of all teenagers at risk of graduating by the second survey date who actually graduate by the second survey date. In the NLSY97, home computer access is determined between the ages of 15-17 and high school graduation is measured by age 19. Using these definitions of high school graduation, we do not capture individuals eventually returning to complete high school or a GED after age 19 in the NLSY97 or after the second survey year in the CPS. $^{10}$

For both measures, high school graduation rates are much higher among teenagers with access to a home computer than teenagers without access to a home computer. Estimates from

\footnotetext{
${ }^{9}$ High school graduation includes obtaining both high school diplomas and GEDs. Although there are concerns about the equivalence of the two degrees, we combine them because the CPS only provides GED information for respondents who have graduated from high school and obtain no additional education, the very small percent of GEDs in our measure of high school graduation, and the unreliability of the GED measure in the CPS (Chaplin 2002).

${ }^{10}$ Dropping out of school, however, is associated with a much lower probability of returning to and completing high school. For example, estimates from the NLSY indicate that 50 percent of dropouts from 1979-1986 returned to school by 1986 (Chuang 1997), and estimates from the CPS indicate that only 42 percent of 22-24 year olds who did not complete high school received a GED (U.S. Department of Education 2001).
} 
the CPS indicate that 73.3 percent of teenagers who have home computers graduate from high school by the following year, compared to only 56.7 percent of teenagers who do not have home computers. Estimates from the NLSY97 provide evidence of a similarly large difference in graduation rates. Nearly 95 percent of children who had a home computer between the ages of 15-17 graduated from high school by age 19 compared to only 70.7 percent of children who did not have a home computer.

The differences in graduation rates are not only large in absolute terms, but are large relative to differences across other observable parental and family characteristics. Estimates from the CPS indicate that the 16.6 percentage point difference in graduation rates is not substantially lower than the difference in graduation rates between teenagers who have college-educated and high-school dropout fathers (19.7 percentage points), have college-educated and high-school dropout mothers (20.7 percentage points), and live in families with incomes of \$75-100,000 and \$20-30,000 (19.2 percentage points). The difference is larger than the white/black difference of 13.4 percentage points.

Estimates from the CPS and NLSY97 clearly indicate that teenagers with home computers are more likely to graduate from high school than children without home computers. The difference in graduation rates is large and not much smaller than differences generated by extreme changes in parental education or family income. Although these estimates do not control for other factors, such as parental education and family income, they are suggestive of the direction and size of potential impacts.

\section{Estimating the Effects of Home Computers on High School Graduation}

To control for parental education, family income and other characteristics, we estimate probit regressions for the probability of graduating from high school using the two datasets. We discuss the results from the CPS first, which are reported in Table 3. All specifications include the sex, race, immigrant status and age of the child, number of children in the household, family 
income, home ownership, mother's and father's presence in the household, education level, labor force status and occupation, region of the country, central city status, and the state-level unemployment rate, average expenditures per pupil and dummy variables for the age requirements of compulsory schooling laws in addition to home computers. ${ }^{11}$ These independent variables are measured in the first survey year prior to measurement of high school graduation. Mother's and father's education level generally have a positive effect (although not statistically significant) on the graduation probability and home ownership has a positive effect on graduation. Latino children, boys, and children with many siblings are less likely to graduate from high school, all else equal.

Home computers are associated with graduating from high school by the following year. The coefficient estimate on the home computer variable is large, positive, and statistically significant. The reported marginal effect indicates that having a home computer is associated with an 8.1 percentage point higher probability of graduating from high school. ${ }^{12}$ The effect of this variable on the probability of high school graduation is roughly comparable in magnitude to that implied by being a girl or owning a home. It is also less than one half the raw difference in high school graduation rates reported in Table 2.

\section{ADDITIONAL PROBIT ESTIMATES}

One concern with these results is that some students may have limited exposure to recently purchased computers, thus reducing the estimated effect on high school graduation. Although the CPS does not provide information on the timing of when all computer purchases were made, it provides information on when the newest computer was obtained by the family. To insure longer exposure to having a computer and to further eliminate concerns regarding reverse

\footnotetext{
${ }^{11}$ State-level unemployment rates are from Bureau of Labor Statistics (2002), and the age requirements for compulsory schooling laws and average expenditures per pupil are from U.S. Department of Education (2002).

${ }^{12}$ We also estimate a specification that includes Internet access at home in addition to home computer. The coefficient estimate on home Internet access is small, negative and statistically insignificant.
} 
causation or joint determination, we include an additional dummy variable measuring whether the newest computer was purchased in the first survey year (Specification 2). A problem with this measure is that a computer purchased in the first survey year may represent a replacement for an older model. The coefficient on home computer, which now measures the relationship for computers purchased at the latest in the year prior to the first survey year (or 21-34 months prior to measurement of high school graduation), is very similar to the original coefficient. The interaction coefficient is small and statistically insignificant. Therefore, the large estimated relationship between home computers and high school graduation is not sensitive to the inclusion of recently purchased computers.

Although not reported, we also estimate a specification that includes the number of computers per person in the household. A limitation of the data, however, is that the measure of the number of computers in the CPS is censored at 3. Thus, we include a per capita measure for households with 1 or 2 computers and a dummy variable for 3 or more computers. We find a large, positive and nearly statistically significant coefficient on the per capita computer measure. We also find a positive and statistically significant coefficient on the dummy variable for three or more computers. Although we do not have complete information on the number of computers, the results indicate that the level of access to home computers is also associated with the probability of graduating from high school.

In the spirit of the "pencil test" presented in DiNardo and Pischke (1997), we also examine whether cable television is associated with a higher probability of graduating from high school. The 2003 CPS includes information on whether the household has cable television. Because we do not expect access to cable television to increase the probability of high school graduation among teenagers, the finding of a similarly sized coefficient estimate as the one for home computers may indicate that the estimated home computer effect is simply capturing the correlation with an unobserved family characteristic. We find a small and statistically insignificant coefficient on the cable television dummy variable when it is included alone or in 
addition to the home computer dummy variable. ${ }^{13}$ The coefficient on home computer remains large, positive and statistically significant.

\section{BIVARIATE PROBIT ESTIMATES FROM THE CPS}

Although the probit models include numerous controls for individual, parental, and family characteristics, estimates of the effects of home computers on high school graduation may be biased. For example, if children with higher levels of academic ability or children with more "educationally motivated" parents are more likely to have access to home computers, then the probit estimates may overstate the effects of home computers on high school graduation. On the other hand, if parents of children with less academic ability or time to spend with their children are more likely to purchase computers, then the probit estimates may understate the effects. In either case, the effects of unobserved factors, such as academic ability and parental motivation, may invalidate a causal interpretation of the previous results.

A potential solution to this problem is to estimate a bivariate probit model in which equations for the probability of high school graduation and the probability of having a home computer are simultaneously estimated. We use dummy variables for whether the child's mother and father use the Internet at work and whether another teenager is present in the household as exclusion restrictions. These three variables should affect the probability of purchasing a computer, but should not have a large effect on high school graduation (after controlling for family income, parental education and parental occupations). Internet use at work may be associated with higher earnings, but this effect should be controlled for by the inclusion of family

\footnotetext{
${ }^{13}$ The 2003 CPS also includes whether any household member uses a cell phone at home. Unfortunately, we do not have information on whether the child uses the phone versus parental use. Nevertheless, we included a dummy variable for cell phone use by a household member. The home computer coefficient is insensitive to the inclusion of the cell phone dummy, and remains large, positive and statistically significant. The cell phone coefficient estimate is large, positive and of similar magnitude to the home computer coefficient when included alone or in combination with home computer. The cell phone coefficient in a bivariate probit model similar to the one discussed below, however, is close to zero.
} 
income. Similarly, the presence of an additional teenager is unlikely to have a large effect on high school graduation after controlling for the number of children in the household.

Before discussing the bivariate probit results, we provide evidence on the validity of these exclusion restrictions by examining their correlation with having a home computer and high school graduation. Estimates are reported in Table 4. Computer ownership rates are higher when the mother uses the Internet at work, the father uses the Internet at work, and there is another teenager present in the household indicating that all three exclusion restrictions are strongly correlated with having a home computer. ${ }^{14}$ The raw data, however, also indicate that the exclusion restrictions and high school graduation rates are correlated. High school graduation rates are higher for children with parents who use the Internet at work and are lower for children living in households with another teenager present. Although the latter correlations raise concerns regarding the validity of the exclusion restrictions, when we control for other factors in probit regressions we do not find evidence of a relationship between any of the exclusion restrictions and high school graduation probabilities (see Table 4). ${ }^{15}$ Although this is not a formal test of the validity of the instruments, it suggests that they are correlated with home computers, but do not have a strong independent correlation with high school graduation.

Estimates from the bivariate probit model for the probability of high school graduation and having a home computer are reported in Specification 3 of Table 3. We first briefly discuss the results for the home computer equation reported in the first column of Specification 3. The probability of owning a home computer generally increases with parental education. Education may be a proxy for wealth or permanent income and have an effect on the budget constraint or may have an effect on preferences for computers through pure tastes, exposure, perceived usefulness, or conspicuous consumption. Family income and home ownership are also important

\footnotetext{
${ }^{14}$ All of these variables also have large, positive and statistically significant coefficients in probit regressions for the probability of having a home computer after controlling for other factors.

${ }^{15}$ We find similar results when these variables are included in the high school graduation equation of the bivariate probit discussed below. They are individually and jointly insignificant.
} 
determinants of owning a computer. The estimated positive relationships are likely to be primarily due to their effects on the budget constraint through income and wealth, however, they may also be due to effects on preferences. African-American and Latino children have lower probabilities of having a home computer than do white children, all else equal.

All three excluded variables have large, positive and statistically significant coefficients in the home computer equation. Father's Internet use at work, mother's Internet use at work and having an additional teenager increase the probability of having a home computer by 6.1, 4.5 and 5.0 percentage points, respectively.

The second column in Specification 3 reports the bivariate probit results for the high school graduation equation. The coefficient estimate on home computers remains large and positive, but is no longer statistically significant. The point estimate implies that the presence of a home computer increases the probability of school enrollment among children by 9.6 percentage points. The magnitude of the estimate is comparable to the probit estimate. In fact, we cannot reject the null hypothesis that the unobserved factors affecting home computer ownership and high school graduation are uncorrelated (i.e. $\rho=0$ ). The test statistic is very small providing evidence that the original probit estimates are consistent and that estimation of the bivariate probit may not be needed.

Focusing on the estimation of non-linear models, such as the bivariate probit, in the presence of binary outcomes and endogenous regressors has been criticized because of their reliance on functional form assumptions (see Angrist 2001 for example). To partly address the concern that our estimates are the result of the non-linearity of the bivariate probit, we estimate the model with two-stage least squares. Estimates for the second-stage high school graduation regression are reported in Specification 4. The first stage regressions are not reported, but include the same controls and additional variables as the home computer equation reported in Specification 3. In the 2SLS regression, the coefficient estimate on home computer is roughly similar in magnitude to the bivariate probit marginal effect estimate (0.1067 compared to 0.0961). 
The standard error, however, is large and the coefficient estimate is not statistically significant. Although the statistical imprecision is troubling and we cannot rule out zero effects with the 2SLS estimates, we are at least reassured that the estimates are similar to the bivariate probit estimates. The bivariate probit estimates do not appear to be driven simply by the functional form of the model. The results of a Hausman test also provide no evidence that home computers are endogenous in the 2SLS model and that OLS estimates are biased. The OLS estimates are very similar to the probit marginal effects and are statistically significant.

Returning to the bivariate probit model, we also check the sensitivity of the bivariate probit estimates to various combinations of the exclusion restrictions. Although we do not find evidence that the original probit estimates are inconsistent, the analysis is useful for completeness and addresses concerns that one of the excluded variables is problematic. Specifically, we estimate bivariate probit models in which we remove mother's Internet use at work (which had the weakest relationship with home computers), and use only father's Internet use at work or the presence of another teenager as the exclusion restriction. In all cases, the coefficient estimate on home computer is large, positive and roughly similar in magnitude to the original estimates. None of the coefficients, however, is statistically significant. Overall, the home computer coefficient estimate is not sensitive to the choice of exclusion restrictions in the bivariate probit models.

As a final check of the sensitivity of the bivariate probit estimates, we add another exclusion restriction to the model. If network effects exist in the adoption of computers then the rate of computer ownership in the local area should affect the probability of owning a computer (Goolsbee and Klenow 2002). At the same time, local levels of computer ownership should not have a large effect on high school graduation rates after controlling for education, family income, and home ownership. Therefore, we use computer ownership rates in the metropolitan area as an additional exclusion restriction in the bivariate probit. Estimates are reported in Specification 4 
of Table 5. The addition of this exclusion restriction has little effect on the home computer coefficient estimate.

The findings from the bivariate probit and 2SLS models do not contradict our original findings of a positive association between having a home computer and graduating from high school from probit regressions. Although the estimated magnitude of the relationship is roughly similar in the probit, bivariate probit and 2SLS models, there is no evidence of correlated unobservables, and the bivariate probit estimates are not sensitive to different estimation techniques and exclusion restrictions, we are still left with some uncertainty because of the lack of precision in the bivariate probit and 2SLS estimates. We now turn to an analysis of the relationship using data from the NLSY97.

\section{ESTIMATES FROM THE NLSY97}

Estimates from probit regressions for the probability of graduating from high school using the NLSY97 are reported in Table 6. The dependent variable equals one if the individual graduates from high school by age 19. Computer ownership is measured between ages 15-17 and most other variables are measured in the first survey year, 1997. ${ }^{16}$ All specifications include similar individual, parental, and family characteristics as in the CPS specifications. In addition to these controls, we include dummy variables for more detailed living arrangements, whether the child's mother was a teen mother, whether any grandparent is a college graduate, household net worth and a continuous measure of household income in Specification 1. High school graduation generally increases with parents' and grandparent's education, household net worth and household income.

The NLSY97 provides additional evidence of a strong positive relationship between computer ownership and high school graduation after controlling for individual, parental and family characteristics. The coefficient estimate on home computer is large, positive and

\footnotetext{
${ }^{16}$ Children living alone in 1997 are excluded from the sample.
} 
statistically significant. Having a home computer as a teenager is associated with a 0.0685 higher probability of graduating from high school. ${ }^{17}$ The coefficient estimate implies a larger difference in graduation probabilities than either having a college graduate mother or having a college graduate father (relative to high school dropouts).

The NLSY97 also includes information on religion and private school attendance. ${ }^{18}$ We include these measures as additional controls in Specification 2. Their inclusion has little effect on the home computer coefficient estimate. To further account for potential unobserved factors correlated with having a home computer we add two typically unobservable measures of the home environment in Specification 3 -- whether a language other than English is spoken at home and whether there is a quiet place to study at home. Although the coefficient is insignificant at conventional levels, speaking another language at home is associated with a lower probability of graduation. The coefficient on whether there is a quiet place to study is very small and statistically insignificant. The addition of these home environment controls has no effect on the estimated relationship between home computers and high school graduation.

As a final sensitivity check, we estimate a specification that includes a dummy variable indicating whether the child takes extra classes or lessons, such as music, dance, or foreign language lessons. This variable is likely to represent a good proxy for educational motivation. Indeed, we find a positive and statistically significant coefficient on the variable. Even after controlling for this variable, however, we continue to find a strong positive relationship between access to a home computer and high school graduation.

Estimates from the NLYS97 indicate that home computers are associated with more than a 0.06 higher probability of graduating from high school, which is similar in magnitude to the estimates from the CPS. These estimates are extremely robust to controlling for the exceptionally

\footnotetext{
${ }^{17}$ We find a larger positive coefficient when the dependent variable is high school graduation in the last survey year, 2002.

${ }^{18}$ Enrollment in private school may not be exogenous (see Altonji, Elder and Taber 2002 for a discussion of the endogeneity issues).
} 
rich set of individual, parental, family and home environment characteristics available in the NLSY97.

\section{DICTIONARIES AS A PENCIL TEST}

The NLSY97 provides another "pencil test" for interpreting the estimated relationship between home computers and high school graduation. The NLSY97 includes information on whether a dictionary is present in the household. It is likely that the presence of a dictionary is correlated with the educational motivation of the family, but it is unlikely that dictionaries have a large effect on educational outcomes. A dictionary may be useful for completing some school assignments, but it is unlikely to have a discernable effect on the likelihood that a child graduates from high school. Specification 5 of Table 6 reports estimates from a model that includes the home dictionary variable. The coefficient estimate on the presence of a dictionary at home is statistically insignificant and is much smaller than the home computer estimate. The home computer estimate is now 0.0632 , which is only slightly smaller than the previous specification. Finally, we find a small and statistically insignificant coefficient estimate on the presence of a dictionary at home when we include it without the home computer variable. These results provide additional evidence that is consistent with the hypothesis that the presence of home computers increases the probability of graduating from high school.

\section{GRADES AND HOME COMPUTERS}

Estimates from the CPS and NLSY97 indicate a strong positive relationship between home computers and high school graduation, however, we know very little about the underlying causes of this relationship. The similarity of the bivariate probit results and the rich set of controls included in the NLSY97 regressions suggest that the relationship is not solely driven by an unobserved factor. An examination of the relationship between home computers and 
additional educational outcomes may shed some light on the underlying causes of the relationship and provide further evidence on the educational impacts of home computers.

The NLSY97 includes information on overall grades obtained in high school, which can be used to estimate the student's grade point average (GPA). The theoretical model presented above indicates that home computers may increase GPAs by making it easier to complete school assignments, keeping children out of trouble, or increasing interest in schoolwork. On the other hand, home computers may decrease GPAs by providing a distraction through video games or emphasizing presentation over content.

Table 7 reports estimates for linear regressions for GPAs. ${ }^{19}$ The mean GPA in the sample is a 2.8 or roughly a B- average. We include the same sets of control variables as those reported in Table 6. Home computers are associated with higher GPAs. The coefficient on home computer is large, positive and statistically significant. It corresponds to an increase of 0.213 points, which is roughly two thirds the value of a plus or minus grade. The implied effect is comparable in magnitude to having a college-educated mother.

In Specifications 2-4 we include the additional measures of religion, private school, home environment and whether the youth attends extra classes. Although some of these variables have large effects on GPAs, the coefficient estimate on home computer is not sensitive to their inclusion. Specification 5 reports the results of our "pencil test" using the presence of a dictionary at home. The coefficient is relatively small and statistically insignificant and essentially has no effect on the home computer estimate.

These estimates provide further evidence that is consistent with the hypothesis that home computers have a positive effect on educational outcomes. The results also suggest that home computers may affect school performance instead of only affecting the likelihood that a child is enrolled and finishes high school.

\footnotetext{
${ }^{19}$ The measure of GPA in the NLSY97 is categorical capturing major cutoffs. We also estimated an ordered probit model with fewer independent variables and find similar results as the linear regression. We find that home computers have a positive and statistically significant relationship with GPAs.
} 


\section{SCHOOL SUSPENSION}

Personal computers may provide utility from games, email, chat rooms, downloading music, and other non-education uses. Although these types of activities may provide a distraction for children as noted above in the theoretical model, they might reduce delinquency and criminal activities among children, thus increasing the likelihood of graduating from high school. The NLSY97 includes detailed information on delinquency and criminal activities. We first present results for the relationship between home computers and school suspension. Probit estimates for the probability of being suspended from school in the survey year are reported in Table 8. Access to a home computer is measured in the year prior to the school suspension measure. In our sample, 11.3 percent of children in any given year experience a suspension from school.

Having a home computer is associated with a lower probability of school suspension. The coefficient estimate is large, negative and statistically significant. Children who have access to a home computer are 2.8 percentage points less likely to be suspended from school than are children who do not have a home computer. The estimated effect is not sensitive to the inclusion of the additional controls. Even after including detailed home environment controls and whether the child takes extra classes, the coefficient estimate on home computer remains large, negative and statistically significant and similar to the estimate in the base specification. The coefficient is also not sensitive to the inclusion of the presence of a home dictionary. The presence of a dictionary at home is not associated with being suspended from school with or without controlling for home computers.

The time-series variation in this variable allows us to estimate two additional models that may help identify causal effects. First, we estimate a fixed effects regression that controls for all unobserved individual, parental and family characteristics that do not change over time. The estimates are reported in Specification 1 of Table 9. The home computer effect is now identified from changes over time in access to home computers and school suspension. The coefficient 
estimate on home computer is smaller in magnitude and now statistically insignificant at conventional levels, but remains somewhat large. The point estimate implies an effect of -0.0090 , which is 8 percent of the mean school suspension probability of 0.1147 . The lack of statistical significance of this estimate, however, may be due to the relatively short time span and lack of time-series variation in having a home computer. We have at most four years of data for each child while they are in school with 40 percent of children have 3 years or less of data. Less than 20 percent of children experience a change in home computers from one year to the next. Although our sample does not represent an ideal application for a fixed effects model, it is somewhat reassuring that the point estimates from these models do not contradict our previous results.

As a final check of the validity of our results for school suspension we estimate a regression that includes future computer ownership in addition to previous computer ownership. ${ }^{20}$ Future computer ownership may serve as a proxy for unobserved characteristics that are correlated with having a home computer and educational outcomes, but cannot have a causal effect on current school suspension. Thus, the finding of a negative coefficient estimate on future computer ownership of similar magnitude to the coefficient estimate on previous computer ownership is suggestive that the correlation in unobserved factors is the underlying cause of the estimated positive relationship. Specifications 2 to 5 of Table 9 report probit estimates for the probability of school suspension. The coefficient estimate on home computer remains large, negative and statistically significant, whereas the coefficient estimate on future home computer is much smaller and statistically insignificant in 3 out of 4 specifications. Previous computer ownership, not future computer ownership, appears to have a strong negative correlation with the probability of school suspension, which is consistent with the hypothesis that home computers have a positive effect on educational outcomes. These findings for the relationships between

\footnotetext{
${ }^{20}$ Future computer ownership is measured in the two years after school suspension is measured.
} 
home computers, future home computers and school suspension are also consistent with Schmitt and Wadsorth's (2004) findings for school examinations.

\section{CRIMINAL ACTIVITIES}

If home computers reduce criminal activities then they may have an indirect effect on educational outcomes. We investigate this hypothesis by estimating separate probit regressions for the probability of committing any criminal activity, being arrested, and gang activity. Estimates are reported in Table 10 for the main specification, a specification that includes the presence of a dictionary at home, a fixed effects model, and a specification that includes future home computers. We first discuss the results for children committing any criminal activity, which includes damaging property, stealing, other property crimes, assaults, and selling drugs. The reported coefficient estimates for home computers are generally negative, but are not statistically significant at conventional levels. Most of the point estimates imply large effects, roughly equal to about 5 percent of the mean. The coefficient estimate on the presence of a dictionary is negative, but has a large standard error, and the coefficient on future home computers is positive, but statistically insignificant.

Table 10 also reports estimates for regressions for the probability of arrests. The coefficients are large, negative and statistically significant in most of the specifications. The fixed effects estimate is not significant at conventional levels and is smaller than the other coefficient estimates, but implies a large effect. Home computers are associated with a decrease in the probability of being arrested by 0.0080 to 0.0179 . The average arrest probability in the sample is 0.06 . The presence of a dictionary at home and future computer ownership appear to have no relationship with arrests.

The coefficient estimates on home computers in the regressions for the probability of being in a gang are large and negative in all specifications. None of the coefficient estimates, however, is statistically significant at conventional levels. The coefficient estimate on future 
home computers is very small, but the coefficient on the presence of a dictionary is negative and large, although not statistically significant.

Overall, the estimates provide some limited evidence of a negative relationship between home computers and criminal activities. The most consistent and statistically significant results are for arrests. For the other criminal activity measures, many of the coefficient estimates are large and negative and consistent across specifications, but are not statistically significant.

\section{Conclusions}

The personal computer is ubiquitous in the classroom, however, one quarter of all children in the United States do not have access to a home computer. Surprisingly little previous research has examined the educational consequences of this disparity in access to technology. In this study, we contribute to the scant literature on the impacts of home computers by exploring the relationship between computer ownership and high school graduation and other educational outcomes using recent panel data from matched CPS files and the NLSY97. A simple theoretical model of the high school graduation decision illustrates the mechanisms by which home computers may affect graduation, but does not offer a prediction of the net effect.

To identify the causal effects of home computers on high school graduation and other education outcomes we employ several empirical strategies. We first estimate probit regressions for the probability of high school graduation using panel data from the CPS and NLSY97. We find that home computers are associated with a 6-8 percentage point higher probability of graduating from high school even after controlling for numerous individual, parental, family and home environment characteristics, including several typically unobservable ones using the NLYS97. Although we find no evidence indicating that the probit estimates are biased, we also estimate bivariate probit models for the joint probability of computer ownership and high school graduation to further rule out the effects of unobserved factors. Using parental use of the Internet at work and the presence of another teenager in the household as exclusion restrictions, we find 
coefficient estimates that are similar to the original probit estimates, although statistically insignificant. The estimation of 2SLS models and several additional bivariate probits provide very similar estimates of the magnitude of the relationship, however, these estimates are also statistically insignificant.

The results from "pencil tests" using the CPS and NLSY97 are consistent with the hypothesis that home computers increase the likelihood of children graduating from high school. Cable television and the presence of dictionaries at home may be correlated with unobserved family characteristics, but are unlikely to have discernable effects on the probability of graduating from high school. Estimates from the CPS indicate that cable television is not correlated with high school graduation, and estimates from the NLYS97 indicate that the presence of a dictionary at home is not correlated with high school graduation. The estimated relationship between home computers and high school graduation is also not sensitive to the inclusion of these variables.

Estimates from the NLSY97 also indicate a strong positive relationship between home computers and grades and a strong negative relationship between home computers and school suspension. To identify causal effects, we estimate fixed effects models and specifications that include future computer ownership for school suspension. The fixed effects estimates, which control for individual, parental and family unobservable characteristics that do not change over time, are smaller in magnitude and insignificant, but continue to imply nontrivial effects. We also find that future computer ownership does not have a strong negative correlation with school suspension, whereas previous computer ownership continues to have a strong negative correlation. Finally, we find some limited evidence suggesting that home computers may decrease crime. The estimates also suggest that home computers may increase high school graduation partly by reducing non-productive activities, such as truancy and crime, among children.

The general consistency of the sign and magnitude of estimates across datasets, inclusion of different sets of controls, timing of computer purchases, exclusion restrictions, and estimation 
strategies suggests that home computers are likely to have positive effects on educational outcomes. The main weakness of the analysis is that some of the techniques, such as the bivariate probits, 2SLS, and fixed effects models, produced imprecisely measured coefficients. On the other hand, the probit models, "pencil tests" and future home computer results provide more precise estimates that are consistent with the hypothesis that home computers improve educational outcomes. Although this study provides a comprehensive analysis of the two main U.S. datasets that include recent information on computer ownership among children, additional evidence on this important question, especially from random experiments, is needed.

The findings presented here have important policy implications. They suggest that disparities in access to technology are likely to translate into future disparities in educational and economic outcomes, thus making the low rates of access to home computers among disadvantaged minorities and poor children especially alarming. Policies that address the financial, informational and technical constraints limiting the optimal level of investment in personal computers among disadvantaged families may be needed. The numerous and increasingly popular state and local programs that provide laptop computers to schoolchildren represent one solution. Tax breaks or special loans for educational computer purchases, training programs, and computer donations represent a few additional examples. The findings also raise concerns about funding cuts for technology-related programs affecting disadvantaged groups, such as community technology centers (Servon 2002). Finally, home computers in the educational process may become more important over time as schools are increasingly digitizing content and there is growing momentum for the controversial issue of replacing textbooks with CD ROMs or Internet-based materials. ${ }^{21}$

\footnotetext{
${ }^{21}$ One of the action steps included in the new U.S. Department of Education's (2004b) National Education Technology Plan is to "move away from reliance on textbooks to the use of multimedia or online information (digital content)."
} 


\section{References}

Altonji J.G., T. E. Elder, C. Taber (2002). “An Evaluation of Instrumental Variable Strategies for Estimating the Effect of Catholic Schools.” NBER \#9358.

Angrist, Joshua. 2001. Estimation of Limited Dependent Variable Models With Dummy Endogenous Regressors: Simple Strategies for Empirical Practice. Journal of Business and Economic Statistics, 19(1): 2-28.

Angrist, Joshua, and Victor Lavy. 2002. "New Evidence on Classroom Computers and Pupil Learning," The Economic Journal, 112 (October), 735-65.

Attewell, Paul, and Juan Battle. 1999. "Home Computers and School Performance," The Information Society, 15: 1-10.

Bureau of Labor Statistics. 2002. State and Regional Unemployment, 2001 Annual Averages. ftp://ftp.bls.gov/pub/news.release/srgune.txt.

Center for Human Resource Research. 2003. NLSY97 Users' Guide, Columbus, Ohio: The Ohio State University.

Chaplin, Duncan. 2002. Tassels on the Cheap. Education Next, Fall: 24-29.

Chuang, Hwei-Lin. 1997. "High School Youths' Dropout and Re-Enrollment Behavior," Economics of Education Review, 16(2): 171-186.

Crandall, Robert W. 2000. "Bridging the Digital Divide: Universal Service, Equal Access, and the Digital Divide," paper presented at Bridging the Digital Divide: California Public Affairs Forum, Stanford University.

Cuban, Larry. 2001. Oversold and Underused: Computers in the Classroom. Cambridge: Harvard University Press.

DiNardo, J., \& Pischke, J.S. (1997). The returns to computer use revisited: Have pencils changed the wage structure too? The Quarterly Journal of Economics 112(1), 291-304.

Fairlie, Robert W. 2004. "Race and the Digital Divide," Contributions to Economic Analysis \& Policy, The B.E. Journals 3(1), Article 15: 1-38.

Fairlie, Robert W. 2005. "The Effects of Home Computers on School Enrollment," Economics of Education Review (forthcoming).

Freeman, Richard B. 2002. "The Labour Market in the New Information Economy," National Bureau of Economic Research Working Paper No. 9254.

Fuchs, Thomas, and Ludger Woessmann. 2004. "Computers and Student Learning: Bivariate and Multivariate Evidence on the Availability and Use of Computers at Home and at School." CESIFO Working Paper No. 1321. 
Giacquinta, Joseph, JoAnne Bauer, and Jane Levin. 1993. Beyond Technology's Promise: An Examination of Children's Educational Computing at Home. New York: Cambridge University Press.

Goolsbee, Austan, and Jonathan Guryan. 2005. "The Impact of Internet Subsidies in Public Schools," Review of Economics and Statistics (forthcoming).

Goolsbee, Austan, and Peter J. Klenow. 2002. "Evidence on Learning and Network Externalities in the Diffusion of Home Computers," Journal of Law and Economics, October 2002, Vol XLV (2, part 1), 317-344.

Holzer, Harry J. 1996. What Employers Want: Job Prospects for Less-Educated Workers, New York: Russell Sage Foundation.

Keefe, Dave, Phoebe Farag and Andy Zucker. 2003. Annotated Bibliography of Ubiquitous Computing Evaluations, Ubiquitous Computing Evaluation Consortium, SRI International, Inc.: Arlington, VA.

Kirpatrick, H., and L. Cuban. 1998. "Computers Make Kids Smarter--Right?" Technos Quarterly for Education and Technology, 7:2.

Lenhart, Amanda, Maya Simon, and Mike Graziano. 2001. "The Internet and Education: Findings from the Pew Internet \& American Life Project," Washington, D.C.: Pew Internet \& American Life Project.

Lowther, Deborah L., Steven M. Ross, and Gary R. Morrison. 2001. Evaluation of a Laptop Program: Successes and Recommendations. Paper presented at the National Educational Computing Conference, "Building on the Future," Chicago, IL.

Madrian, Brigette C., and Lars John Lefgren. 2000. "An Approach to Longitudinally Matching Current Population Survey (CPS) Respondents," Journal of Economic and Social Measurement, 26, 31-62.

Mitchell Institute. 2004. One-to-one Laptops in a High School Environment, Piscataquis Community High School Study Final Report. Great Maine Schools Project.

Noll, Roger G. Noll, Dina Older-Aguilar, Gregory L. Rosston, and Richard R. Ross. 2000. "The Digital Divide: Definitions, Measurement, and Policy Issues," paper presented at Bridging the Digital Divide: California Public Affairs Forum, Stanford University.

Novak, Tomas P., and Donna L. Hoffman. 1998. "Bridging the Digital Divide: The Impact of Race on Computer Access and Internet Use." Owen Graduate School of Management, Vanderbilt University Working Paper.

Peck, Craig, Larry Cuban, and Heather Kirkpatrick. 2002. "Techno-Promoter Dreams, Student Realities," Phi Delta Kappan. 83:6, 472-80.

Puma, Michael J., Duncan D. Chaplin, and Andreas D. Pape. 2000. E-Rate and the Digital Divide: A Preliminary Analysis from the Integrated Studies of Educational Technology. Urban Institute. 
Rockman, et al. 2000. A More Complex Picture: Laptop Use and Impact in the Context of Changing Home and School Access. A Project for Anytime Anywhere Learning by Microsoft Corporation.

Rouse, Cecilia E., and Alan B. Krueger. 2004. "Putting Computerized Instruction to the Test: A Randomized Evaluation of a "Scientifically-Based" Reading Program," Economics of Education Review, 23(October): 323-38.

Selwyn, Neil. 1998. "The Effect of Using a Home Computer on Students' Educational Use of IT," Computers and Education, 31: 211-227.

Servon, Lisa. 2002. Bridging the Digital Divide: Community, Technology and Policy (Blackwell).

Schmitt, John, and Jonathan Wadsworth. 2004. "Is There an Impact of Household Computer Ownership on Children's Educational Attainment in Britain? Centre for Economic Performance Discussion Paper No. 625.

Silvernail, David L., and Dawn M. M. Lane. 2004. The Impact of Maine's One-to-One Laptop Program on Middle School Teachers and Students, Phase One Summary Evidence, Research Report \#1. Maine Education Policy Research Institute, University of Southern Maine Office.

SRI International. 2002. The Integrated Studies of Educational Technology: Professional Development and Teachers' Use of Technology," SRI International Report.

Stevenson, Kenneth R. 1999. Evaluation Report - Year 3, Middle School Laptop Program, Beaufort County School District. University of South Carolina.

Stoll, Clifford. 1995. Silicon Snake Oil: Second Thoughts on the Information Highway. New York: Doubleday.

Underwood, J., Billingham. M. and Underwood, G. 1994. "Predicting Computer Literacy: How Do the Technological Experiences of Schoolchildren Predict Their Computer Based ProblemSolving Skills? Journal of Information Technology for Teacher Education, 3(1), 115-125.

Urban-Lurain, Mark, and Yong Zhao. 2004. Freedom to Learn Evaluation Report: 2003 Project Implementation Executive Summary, Prepared for Michigan Virtual University by The Center for Teaching and Technology Michigan State University.

U.S. Department of Commerce. 2002. A Nation Online: How Americans are Expanding Their Use of the Internet. Washington, D.C.: U.S.G.P.O.

U.S. Department of Education. 2001. Dropout Rates in the United States: 1999. Washington, D.C.: National Center for Education Statistics.

U.S. Department of Education 2002. National Center for Education Statistics. Digest of Education Statistics, 2001,NCES 2002-130, by Thomas D. Snyder. Production Manager, Charlene M. Hoffman. Washington, DC. 
U.S. Department of Education. 2004a. National Center for Education Statistics. Internet Access in U.S. Public Schools and Classrooms: 1994-2002, NCES 2004-011, by Anne Kleiner and Laurie Lewis. Project Officer: Bernard Greene. Washington, DC: 2003.

http://nces.ed.gov/pubs2004/2004011.pdf

U.S. Department of Education. 2004b. Office of Education Technology. Toward a New Golden Age in American Education: How the Internet, the Law, and Today's Students are Revolutionizing Expectations. Washington, DC: 2004.

http://nationaledtechplan.org/default.asp

Universal Services Administration Company. 2003. Annual Report

http://www.universalservice.org/download/pdf/2003AnnualReport.pdf

Valletta, Robert G. 2004. "The Computer Evolution: Diffusion and Changing Returns in the U.S., 1984-2001, Federal Reserve Bank of San Francisco Working Paper. 
Table 1

Home Computer Use among Children Ages 16-18

Current Population Survey, 2003

\begin{tabular}{|c|c|c|c|}
\hline & \multicolumn{3}{|c|}{ Enrolled in } \\
\hline & All Children & School & Not Enrolled \\
\hline $\begin{array}{l}\text { Percent of children with access to a } \\
\text { home computer }\end{array}$ & $79.6 \%$ & $81.1 \%$ & $56.4 \%$ \\
\hline Sample size & 4,388 & 4,119 & 269 \\
\hline $\begin{array}{l}\text { Percent of children with access to a } \\
\text { home computer who use that computer }\end{array}$ & $94.6 \%$ & $95.2 \%$ & $81.6 \%$ \\
\hline Sample size & 3,543 & 3,392 & 151 \\
\hline \multicolumn{4}{|l|}{ Percent of home computer users who: } \\
\hline use computer for school assignments & $93.4 \%$ & $93.4 \%$ & \\
\hline use computer for the Internet & $86.9 \%$ & $87.4 \%$ & $74.5 \%$ \\
\hline use computer for games & $72.6 \%$ & $72.9 \%$ & $64.9 \%$ \\
\hline use computer for electronic mail & $78.2 \%$ & $78.8 \%$ & $62.9 \%$ \\
\hline use computer for word processing & $70.0 \%$ & $71.1 \%$ & $38.8 \%$ \\
\hline use computer for graphics and design & $45.0 \%$ & $45.5 \%$ & $33.4 \%$ \\
\hline $\begin{array}{l}\text { use computer for spreadsheets or } \\
\text { databases }\end{array}$ & $22.1 \%$ & $22.3 \%$ & $16.1 \%$ \\
\hline Sample size & 3,357 & 3,234 & 123 \\
\hline
\end{tabular}


Table 2

High School Graduation Rates

Matched Current Population Surveys (2000-2004) and NLSY97

No home Home

computer computer Difference

High school graduation rate by second survey year CPS

$56.7 \% \quad 73.3 \% \quad 16.6 \%$

Sample Size

308

1,419

High school graduation rate by age 19

NLSY97

$70.7 \% \quad 94.2 \% \quad 23.5 \%$

Sample Size

659

3,280

Notes: (1) The CPS sample consists of teenagers ages 16-18 who have completed 11th or 12th grade, but have not received a high school diploma in the first survey year. (2) All estimates are calculated using sample weights provided by the CPS and NLSY97. 
Table 3

Probit, Bivariate Probit and 2SLS Regressions for High School Graduation and Home Computer Matched Current Population Surveys, 2000-2004

Specification

Explanatory variables

Dependent variable

Model type

Female

Black

Latino

Immigrant

Family income: missing

Family income: $\$ 15,000$ to $\$ 30,000$

Family income: $\$ 30,000$ to $\$ 50,000$

Family income: $\$ 50,000$ to $\$ 75,000$

Family income: greater than $\$ 75,000$

Home ownership

Mother-high school graduate

Mother-some college

Mother-college graduate

Father-high school graduate

Father-some college

Father-college graduate
(1)

HS Grad HS Grad

Probit

0.0649

$(0.0267)$

Probit

0.0648

$(0.0267)$

$-0.0319$

$-0.0318$

$(0.0460)$

(0.0459)

$-0.0997 \quad-0.0997$

$(0.0513)$

0.0186

$(0.0564)$

0.0186

$(0.0563)$

$-0.0935$

$-0.0938$

$(0.0544)$

$(0.0543)$

$-0.0322$

$(0.0558)$

$-0.0323$

(0.0558)

0.0270

(0.0479)

0.0267

(0.0479)

$-0.0490$

$-0.0494$

(0.0552)

$(0.0550)$

$-0.0093$

$-0.0097$

(0.0519)

(0.0518)

0.0899

0.0900

$(0.0405) \quad(0.0405)$

0.0173

0.0173

(0.0486)

(0.0486)

0.0741

(0.0487)

0.0741

$(0.0487)$

0.0347

0.0349

(0.0578)

(0.0578)

0.0746

(0.0512)

$(0.0512)$

0.0511

$(0.0555)$

(0.0555)

0.0550

0.0550
$(0.0513)$

$\begin{array}{lllll}(0.0610) & (0.0610) & (0.0352) & (0.0627) & (0.0634)\end{array}$

(3)

(4)

Computer HS Grad HS Grad
Bivariate Bivariate

Probit

Probit

2SLS

0.0199

0.0646

0.0618

(0.0172)

$(0.0271)$

(0.0268)

$-0.0652$

$-0.0305$

$-0.0247$

(0.0359)

$(0.0477)$

$(0.0663)$

$-0.1279$

$-0.0974$

$-0.0857$

(0.0431)

(0.0566)

(0.0910)

$-0.0051$

$(0.0317)$

0.0189

0.0300

(0.0571)

(0.0625)

0.0291

$-0.0950$

$-0.0845$

(0.0265)

(0.0549)

(0.0691)

0.0427

$-0.0334 \quad-0.0253$

(0.0234)

(0.0566)

$(0.0673)$

0.0715

0.0248

0.0261

(0.0205)

(0.0551)

(0.0910)

0.0910

$-0.0517$

$-0.0453$

(0.0206)

(0.0638)

(0.1024)

0.0928

$-0.0116$

$-0.0136$

(0.0261)

(0.0581)

(0.0913)

0.0782

0.0882

0.0856

(0.0281)

(0.0436)

(0.0688)

0.0684

(0.0232)

0.0151

0.0220

(0.0561)

(0.0929)

0.0957

(0.0228)

0.0714

0.0743

0.0834

$(0.0600)$

(0.1170)

$(0.0260)$

0.0323

0.0429

(0.0659)

$(0.1101)$

$-0.0626$

(0.0375)

0.0754

0.0774

$(0.0547) \quad(0.0648)$

$\begin{array}{lll}0.0209 & 0.0507 & 0.0479\end{array}$

(0.0329)

(0.0569)

$(0.0594)$ 
Table 3 (continued)

Probit, Bivariate Probit and 2SLS Regressions for

High School Graduation and Home Computer

Matched Current Population Surveys, 2000-2004

Specification

Explanatory Variables

(1)

(2)

Home computer

0.0811

0.0819

$(0.0414)$

$(0.0419)$

(3)

Newest computer purchased in

$-0.0034$

first survey year

(0.0368)

Father uses Internet at work

0.0610

$(0.0232)$

Mother uses Internet at work

0.0454

$(0.0212)$

Another teenager present in household

0.0500

(0.0238)

Mother's occupation controls

Father's occupation controls

$\rho$

Yes Yes

Yes

Yes

Yes

Yes

Yes

Yes

Yes

$-0.0248$

(0.2855)

Mean of dependent variable

0.7050

0.7050

0.8211

0.7050

0.7050

Sample size

1,711

1,711

1,711

1,711

Notes: (1) The sample consists of teenagers ages 16-18 who have completed 11th or 12th grade, but have not received a high school diploma in the first survey year. (2) Marginal effects and their standard errors (in parentheses) are reported. (3) All specifications include a constant, number of children in household, dummy variables for age, region, central city status, survey year, rotation group, mother's and father's presence in the household and labor force status, and the state-level unemployment rate, expenditures per pupil, and age requirements of compulsory schooling laws. (4) All estimates are calculated using sample weights provided by the CPS. 
Table 4

Selected Statistics for Exclusion Restrictions

Matched Current Population Surveys, 2000-2004

\begin{tabular}{|c|c|c|c|c|c|c|}
\hline & \multicolumn{3}{|c|}{ Home computer } & \multicolumn{3}{|c|}{ High shool graduation } \\
\hline & \multicolumn{3}{|c|}{ Probit } & \multicolumn{3}{|c|}{ Probit } \\
\hline & Rate & $\begin{array}{c}\text { Marginal } \\
\text { effect }\end{array}$ & $\begin{array}{c}\text { T- } \\
\text { statistic }\end{array}$ & Rate & $\begin{array}{c}\text { Marginal } \\
\text { effect }\end{array}$ & $\begin{array}{c}\text { T- } \\
\text { statistic }\end{array}$ \\
\hline Father uses the Internet at work & 0.9678 & & & 0.7435 & & \\
\hline Father does not use the Internet work & 0.7430 & & & 0.6841 & & \\
\hline Difference & 0.2248 & 0.0624 & 2.57 & 0.0594 & -0.0475 & -1.22 \\
\hline Mother uses the Internet at work & 0.9359 & & & 0.7586 & & \\
\hline Mother does not use the Internet at work & 0.7531 & & & 0.6793 & & \\
\hline Difference & 0.1828 & 0.0501 & 2.31 & 0.0793 & 0.0081 & 0.23 \\
\hline Another teenager present in household & 0.8270 & & & 0.6762 & & \\
\hline No other teenager present in household & 0.7776 & & & 0.7191 & & \\
\hline Difference & 0.0494 & 0.0528 & 2.14 & -0.0429 & 0.0019 & 0.05 \\
\hline
\end{tabular}

Notes: (1) See notes to Table 3. (2) Probit regressions include the exclusion restriction (alone), and the independent variables listed in Table 3. 
Table 5

Additional Bivariate Probit Regressions

Matched Current Population Surveys, 2000-2004

\begin{tabular}{|c|c|c|c|c|}
\hline & \multirow[b]{2}{*}{ (1) } & \multicolumn{3}{|c|}{ Specification } \\
\hline & & $(2)$ & (3) & $(4)$ \\
\hline Home Computer & $\begin{array}{c}0.0633 \\
(0.1918)\end{array}$ & $\begin{array}{c}0.0675 \\
(0.1985)\end{array}$ & $\begin{array}{c}0.0922 \\
(0.1773)\end{array}$ & $\begin{array}{c}0.0852 \\
(0.1703)\end{array}$ \\
\hline Exclusion Restrictions: & & & & \\
\hline Father uses Internet at work & $\begin{array}{c}0.0674 \\
(0.0268)\end{array}$ & $\begin{array}{c}0.0680 \\
(0.0237)\end{array}$ & & $\begin{array}{c}0.0602 \\
(0.0261)\end{array}$ \\
\hline Mother uses Internet at work & & & & $\begin{array}{c}0.0464 \\
(0.0230)\end{array}$ \\
\hline Another teenager present in household & $\begin{array}{c}0.0494 \\
(0.0240)\end{array}$ & & $\begin{array}{c}0.0512 \\
(0.0247)\end{array}$ & $\begin{array}{c}0.0500 \\
(0.0236)\end{array}$ \\
\hline MSA-level home computer rate & & & & $\begin{array}{c}0.2019 \\
(0.1195)\end{array}$ \\
\hline$\rho$ & $\begin{array}{c}0.0296 \\
(0.3102)\end{array}$ & $\begin{array}{c}0.0226 \\
(0.3256)\end{array}$ & $\begin{array}{c}-0.0182 \\
(0.2828)\end{array}$ & $\begin{array}{c}-0.0067 \\
(0.2740)\end{array}$ \\
\hline Sample Size & 1,711 & 1,711 & 1,711 & 1,711 \\
\hline
\end{tabular}

Note: See notes to Table 3. 
Table 6

Probit Regressions for High School Graduation

NLSY97

Specification

\begin{tabular}{|c|c|c|c|c|c|}
\hline Explanatory variables & (1) & (2) & (3) & (4) & (5) \\
\hline \multirow{2}{*}{ Female } & 0.0225 & 0.0222 & 0.0224 & 0.0214 & 0.0210 \\
\hline & $(0.0065)$ & $(0.0065)$ & $(0.0064)$ & $(0.0063)$ & $(0.0063)$ \\
\hline \multirow[t]{2}{*}{ Black } & 0.0251 & 0.0278 & 0.0266 & 0.0246 & 0.0245 \\
\hline & $(0.0070)$ & $(0.0071)$ & $(0.0070)$ & $(0.0071)$ & $(0.0071)$ \\
\hline \multirow[t]{2}{*}{ Latino } & -0.0037 & -0.0128 & -0.0014 & -0.0007 & -0.0004 \\
\hline & $(0.0098)$ & $(0.0113)$ & $(0.0117)$ & $(0.0116)$ & $(0.0116)$ \\
\hline \multirow[t]{2}{*}{ Asian } & 0.0350 & 0.0336 & 0.0342 & 0.0336 & 0.0333 \\
\hline & $(0.0116)$ & $(0.0121)$ & $(0.0110)$ & $(0.0109)$ & $(0.0112)$ \\
\hline \multirow[t]{2}{*}{ Immigrant } & -0.0165 & -0.0194 & -0.0157 & -0.0148 & -0.0141 \\
\hline & $(0.0156)$ & $(0.0162)$ & $(0.0154)$ & $(0.0152)$ & $(0.0151)$ \\
\hline \multirow[t]{2}{*}{ Lives with mom and step dad } & -0.0338 & -0.0307 & -0.0303 & -0.0273 & -0.0261 \\
\hline & $(0.0152)$ & $(0.0149)$ & $(0.0147)$ & $(0.0142)$ & $(0.0141)$ \\
\hline \multirow[t]{2}{*}{ Lives with dad and step mom } & -0.0425 & -0.0470 & -0.0466 & -0.0439 & -0.0425 \\
\hline & $(0.0331)$ & $(0.0346)$ & $(0.0341)$ & $(0.0333)$ & $(0.0329)$ \\
\hline \multirow[t]{2}{*}{ Lives with mom only } & -0.0346 & -0.0324 & -0.0331 & -0.0324 & -0.0313 \\
\hline & $(0.0110)$ & $(0.0108)$ & $(0.0108)$ & $(0.0107)$ & $(0.0106)$ \\
\hline \multirow[t]{2}{*}{ Lives with dad only } & -0.1173 & -0.1140 & -0.1176 & -0.1165 & -0.1165 \\
\hline & $(0.0396)$ & $(0.0400)$ & $(0.0406)$ & $(0.0404)$ & $(0.0403)$ \\
\hline \multirow[t]{2}{*}{ Lives with guardian } & -0.0637 & -0.0632 & -0.0631 & -0.0632 & -0.0625 \\
\hline & $(0.0237)$ & $(0.0238)$ & $(0.0237)$ & $(0.0237)$ & $(0.0236)$ \\
\hline \multirow[t]{2}{*}{ Mom was teenager at first birth } & -0.0128 & -0.0114 & -0.0111 & -0.0112 & -0.0112 \\
\hline & $(0.0088)$ & $(0.0087)$ & $(0.0086)$ & $(0.0085)$ & $(0.0085)$ \\
\hline \multirow[t]{2}{*}{ Mother high school graduate } & 0.0032 & 0.0022 & 0.0019 & 0.0014 & 0.0008 \\
\hline & $(0.0077)$ & $(0.0077)$ & $(0.0076)$ & $(0.0076)$ & $(0.0076)$ \\
\hline \multirow[t]{2}{*}{ Mother some college } & 0.0217 & 0.0206 & 0.0201 & 0.0188 & 0.0185 \\
\hline & $(0.0082)$ & $(0.0083)$ & $(0.0082)$ & $(0.0082)$ & $(0.0083)$ \\
\hline \multirow[t]{2}{*}{ Mother college graduate } & 0.0474 & 0.0468 & 0.0459 & 0.0452 & 0.0451 \\
\hline & $(0.0083)$ & $(0.0083)$ & $(0.0081)$ & $(0.0081)$ & $(0.0081)$ \\
\hline \multirow[t]{2}{*}{ Father high school graduate } & 0.0274 & 0.0273 & 0.0257 & 0.0247 & 0.0245 \\
\hline & $(0.0074)$ & $(0.0074)$ & $(0.0073)$ & $(0.0073)$ & $(0.0073)$ \\
\hline \multirow[t]{2}{*}{ Father some college } & 0.0248 & 0.0257 & 0.0247 & 0.0235 & 0.0233 \\
\hline & $(0.0083)$ & $(0.0082)$ & $(0.0081)$ & $(0.0081)$ & $(0.0082)$ \\
\hline \multirow[t]{2}{*}{ Father college graduate } & 0.0409 & 0.0407 & 0.0399 & 0.0378 & 0.0376 \\
\hline & $(0.0084)$ & $(0.0083)$ & $(0.0082)$ & $(0.0084)$ & $(0.0084)$ \\
\hline \multirow[t]{2}{*}{ Grandparent college graduate } & 0.0234 & 0.0243 & 0.0234 & 0.0228 & 0.0227 \\
\hline & $(0.0091)$ & $(0.0089)$ & $(0.0089)$ & $(0.0088)$ & $(0.0088)$ \\
\hline
\end{tabular}

(continued) 
Table 6 (continued)

Probit Regressions for High School Graduation

NLSY97

\begin{tabular}{|c|c|c|c|c|c|}
\hline \multirow[b]{2}{*}{ Explanatory variables } & \multicolumn{5}{|c|}{ Specification } \\
\hline & (1) & (2) & (3) & (4) & (5) \\
\hline \multirow[t]{2}{*}{ Household net worth $(10,000 \mathrm{~s})$} & 0.0013 & 0.0014 & 0.0013 & 0.0013 & 0.0014 \\
\hline & $(0.0006)$ & $(0.0006)$ & $(0.0006)$ & $(0.0005)$ & $(0.0006)$ \\
\hline \multirow[t]{2}{*}{ Household net worth squared $(10,000 s)$} & 0.0000 & 0.0000 & 0.0000 & 0.0000 & 0.0000 \\
\hline & $(0.0000)$ & $(0.0000)$ & $(0.0000)$ & $(0.0000)$ & $(0.0000)$ \\
\hline \multirow[t]{2}{*}{ Household income $(10,000 \mathrm{~s})$} & 0.0045 & 0.0042 & 0.0039 & 0.0038 & 0.0037 \\
\hline & $(0.0028)$ & $(0.0028)$ & $(0.0028)$ & $(0.0028)$ & $(0.0028)$ \\
\hline \multirow[t]{2}{*}{ Household income squared $(10,000 s)$} & -0.0001 & -0.0001 & -0.0001 & -0.0001 & -0.0001 \\
\hline & $(0.0002)$ & $(0.0002)$ & $(0.0002)$ & $(0.0001)$ & $(0.0002)$ \\
\hline \multirow[t]{2}{*}{ Private school } & & -0.0230 & -0.0227 & -0.0219 & -0.0216 \\
\hline & & $(0.0152)$ & $(0.0150)$ & (0.0148) & $(0.0148)$ \\
\hline \multirow[t]{2}{*}{ Other language spoken at home } & & & -0.0225 & -0.0226 & -0.0228 \\
\hline & & & $(0.0153)$ & $(0.0154)$ & $(0.0154)$ \\
\hline \multirow[t]{2}{*}{ Quiet place to study in household } & & & 0.0036 & 0.0040 & 0.0028 \\
\hline & & & $(0.0096)$ & $(0.0096)$ & (0.0095) \\
\hline \multirow[t]{2}{*}{ Youth attends extra classes } & & & & 0.0189 & 0.0184 \\
\hline & & & & $(0.0066)$ & $(0.0067)$ \\
\hline \multirow[t]{2}{*}{ Dictionary present in household } & & & & & 0.0168 \\
\hline & & & & & $(0.0147)$ \\
\hline \multirow[t]{2}{*}{ Home computer by age 17} & 0.0685 & 0.0691 & 0.0679 & 0.0648 & 0.0632 \\
\hline & $(0.0133)$ & $(0.0134)$ & $(0.0133)$ & $(0.0130)$ & $(0.0129)$ \\
\hline Religion dummies & No & Yes & Yes & Yes & Yes \\
\hline Mean of dependent variable & 0.9028 & 0.9028 & 0.9027 & 0.9025 & 0.9027 \\
\hline Sample size & 3,715 & 3,673 & 3,670 & 3,650 & 3,648 \\
\hline
\end{tabular}

Notes: (1) The sample in all specifications consists of teenagers living with their parents in 1997. (2) All specifications include a constant, number of children in the household, dummy variables for the quarter of birth, region, central city status, and missing categories for some variables, and school size, student-teacher ratio and local unemployment rate. 
Table 7

OLS Regressions for High School GPA

NLSY97

Specification

\begin{tabular}{|c|c|c|c|c|c|}
\hline Explanatory variables & $(1)$ & $(2)$ & $(3)$ & $(4)$ & $(5)$ \\
\hline \multirow[t]{2}{*}{ Female } & 0.3514 & 0.3502 & 0.3534 & 0.3415 & 0.3400 \\
\hline & $(0.0231)$ & $(0.0232)$ & $(0.0232)$ & $(0.0233)$ & $(0.0233)$ \\
\hline \multirow[t]{2}{*}{ Black } & -0.1406 & -0.1425 & -0.1451 & -0.1590 & -0.1602 \\
\hline & $(0.0329)$ & $(0.0345)$ & $(0.0345)$ & $(0.0345)$ & $(0.0345)$ \\
\hline \multirow[t]{2}{*}{ Latino } & -0.0488 & -0.0566 & -0.0580 & -0.0581 & -0.0586 \\
\hline & $(0.0357)$ & $(0.0376)$ & $(0.0439)$ & $(0.0438)$ & $(0.0439)$ \\
\hline \multirow[t]{2}{*}{ Asian } & 0.2307 & 0.2189 & 0.2176 & 0.2356 & 0.2338 \\
\hline & $(0.0919)$ & (0.0919) & $(0.0928)$ & $(0.0935)$ & $(0.0935)$ \\
\hline \multirow[t]{2}{*}{ Immigrant } & 0.0285 & 0.0312 & 0.0245 & 0.0412 & 0.0432 \\
\hline & $(0.0510)$ & $(0.0513)$ & $(0.0517)$ & (0.0516) & $(0.0516)$ \\
\hline \multirow[t]{2}{*}{ Lives with mom and step dad } & -0.1504 & -0.1475 & -0.1451 & -0.1392 & -0.1396 \\
\hline & (0.0395) & (0.0399) & (0.0399) & $(0.0397)$ & $(0.0397)$ \\
\hline \multirow[t]{2}{*}{ Lives with dad and step mom } & -0.2104 & -0.2254 & -0.2279 & -0.2078 & -0.2072 \\
\hline & $(0.0800)$ & $(0.0805)$ & $(0.0804)$ & $(0.0805)$ & $(0.0806)$ \\
\hline \multirow[t]{2}{*}{ Lives with mom only } & -0.1229 & -0.1216 & -0.1214 & -0.1191 & -0.1189 \\
\hline & $(0.0318)$ & $(0.0320)$ & $(0.0321)$ & $(0.0320)$ & $(0.0321)$ \\
\hline \multirow[t]{2}{*}{ Lives with dad only } & -0.2168 & -0.2178 & -0.2191 & -0.2216 & -0.2234 \\
\hline & $(0.0643)$ & $(0.0649)$ & $(0.0649)$ & $(0.0648)$ & $(0.0648)$ \\
\hline \multirow[t]{2}{*}{ Lives with guardian } & -0.0776 & -0.0808 & -0.0814 & -0.0784 & -0.0806 \\
\hline & $(0.0556)$ & $(0.0562)$ & $(0.0562)$ & $(0.0562)$ & $(0.0562)$ \\
\hline \multirow[t]{2}{*}{ Mom was teenager at first birth } & -0.1141 & -0.1048 & -0.1043 & -0.1051 & -0.1047 \\
\hline & $(0.0332)$ & $(0.0334)$ & $(0.0334)$ & $(0.0334)$ & $(0.0334)$ \\
\hline \multirow[t]{2}{*}{ Mother high school graduate } & 0.0723 & 0.0742 & 0.0737 & 0.0774 & 0.0755 \\
\hline & $(0.0339)$ & $(0.0341)$ & $(0.0341)$ & $(0.0341)$ & $(0.0341)$ \\
\hline \multirow[t]{2}{*}{ Mother some college } & 0.1165 & 0.1137 & 0.1147 & 0.1086 & 0.1069 \\
\hline & $(0.0394)$ & $(0.0396)$ & $(0.0396)$ & $(0.0395)$ & $(0.0395)$ \\
\hline \multirow[t]{2}{*}{ Mother college graduate } & 0.2274 & 0.2208 & 0.2235 & 0.2171 & 0.2155 \\
\hline & $(0.0459)$ & $(0.0460)$ & $(0.0459)$ & $(0.0459)$ & $(0.0459)$ \\
\hline \multirow[t]{2}{*}{ Father high school graduate } & 0.1250 & 0.1243 & 0.1235 & 0.1252 & 0.1250 \\
\hline & $(0.0352)$ & $(0.0354)$ & $(0.0355)$ & $(0.0355)$ & $(0.0355)$ \\
\hline \multirow[t]{2}{*}{ Father some college } & 0.1859 & 0.1868 & 0.1828 & 0.1731 & 0.1726 \\
\hline & $(0.0441)$ & $(0.0442)$ & $(0.0443)$ & $(0.0443)$ & $(0.0443)$ \\
\hline \multirow[t]{2}{*}{ Father college graduate } & 0.2837 & 0.2838 & 0.2790 & 0.2646 & 0.2641 \\
\hline & $(0.0460)$ & $(0.0462)$ & $(0.0462)$ & $(0.0462)$ & $(0.0463)$ \\
\hline \multirow[t]{2}{*}{ Grandparent college graduate } & 0.0918 & 0.0892 & 0.0899 & 0.0848 & 0.0843 \\
\hline & $(0.0353)$ & $(0.0356)$ & $(0.0356)$ & $(0.0355)$ & $(0.0355)$ \\
\hline
\end{tabular}


Table 7 (continued)

OLS Regressions for High School GPA

NLSY97

\begin{tabular}{|c|c|c|c|c|c|}
\hline \multirow[b]{2}{*}{ Explanatory variables } & \multicolumn{5}{|c|}{ Specification } \\
\hline & (1) & (2) & (3) & (4) & (5) \\
\hline \multirow[t]{2}{*}{ Household net worth $(10,000 \mathrm{~s})$} & 0.0052 & 0.0050 & 0.0049 & 0.0047 & 0.0046 \\
\hline & $(0.0016)$ & $(0.0016)$ & $(0.0016)$ & $(0.0016)$ & $(0.0016)$ \\
\hline \multirow[t]{2}{*}{ Household net worth squared $(10,000 s)$} & 0.0000 & 0.0000 & 0.0000 & 0.0000 & 0.0000 \\
\hline & $(0.0000)$ & $(0.0000)$ & $(0.0000)$ & $(0.0000)$ & $(0.0000)$ \\
\hline \multirow[t]{2}{*}{ Household income $(10,000 s)$} & 0.0114 & 0.0126 & 0.0130 & 0.0121 & 0.0120 \\
\hline & $(0.0091)$ & $(0.0092)$ & $(0.0092)$ & $(0.0092)$ & $(0.0092)$ \\
\hline \multirow[t]{2}{*}{ Household income squared $(10,000$ s) } & -0.0005 & -0.0005 & -0.0005 & -0.0005 & -0.0005 \\
\hline & $(0.0004)$ & $(0.0004)$ & $(0.0004)$ & $(0.0004)$ & $(0.0004)$ \\
\hline \multirow[t]{2}{*}{ Private school } & & -0.0279 & -0.0286 & -0.0273 & -0.0297 \\
\hline & & $(0.0419)$ & $(0.0419)$ & $(0.0419)$ & $(0.0420)$ \\
\hline \multirow[t]{2}{*}{ Other language spoken at home } & & & 0.0100 & 0.0059 & 0.0049 \\
\hline & & & $(0.0450)$ & $(0.0450)$ & $(0.0450)$ \\
\hline \multirow[t]{2}{*}{ Quiet place to study in household } & & & 0.1253 & 0.1247 & 0.1197 \\
\hline & & & $(0.0390)$ & $(0.0389)$ & $(0.0393)$ \\
\hline \multirow[t]{2}{*}{ Youth attends extra classes } & & & & 0.1516 & 0.1517 \\
\hline & & & & $(0.0264)$ & $(0.0264)$ \\
\hline \multirow[t]{2}{*}{ Dictionary present in household } & & & & & 0.0540 \\
\hline & & & & & $(0.0545)$ \\
\hline \multirow[t]{2}{*}{ Home computer by age 17} & 0.2163 & 0.2153 & 0.2094 & 0.2060 & 0.2031 \\
\hline & $(0.0329)$ & $(0.0330)$ & $(0.0331)$ & $(0.0330)$ & $(0.0331)$ \\
\hline Religion dummies & No & Yes & Yes & Yes & Yes \\
\hline Mean of dependent variable & 2.8198 & 2.8252 & 2.8268 & 2.8272 & 2.8278 \\
\hline Sample size & 4,067 & 4,008 & 4,001 & 3,978 & 3,975 \\
\hline
\end{tabular}

Note: See notes to Table 6. 
Table 8

Probit Regressions for School Suspension

NLSY97

Specification

Explanatory variables

Female
Black
Latino
Asian
Immigrant
Lives with mom and step dad

Lives with dad and step mom

Lives with mom only

Lives with dad only

Lives with guardian

Mom was teenager at first birth

Mother high school graduate

Mother some college

Mother college graduate

Father high school graduate

Father some college

Father college graduate

Grandparent college graduate
(1)

$\begin{array}{ccccc}-0.0753 & -0.0753 & -0.0768 & -0.0758 & -0.0758 \\ (0.0054) & (0.0054) & (0.0054) & (0.0054) & (0.0054) \\ 0.0220 & 0.0215 & 0.0214 & 0.0209 & 0.0206 \\ (0.0078) & (0.0080) & (0.0081) & (0.0081) & (0.0081) \\ -0.0264 & -0.0279 & -0.0282 & -0.0289 & -0.0293 \\ (0.0074) & (0.0075) & (0.0089) & (0.0089) & (0.0088)\end{array}$

$\begin{array}{lllll}-0.0231 & -0.0195 & -0.0198 & -0.0185 & -0.0187\end{array}$

$\begin{array}{llllll}(0.0199) & (0.0206) & (0.0208) & (0.0212) & (0.0211)\end{array}$

$\begin{array}{lllll}-0.0214 & -0.0190 & -0.0183 & -0.0174 & -0.0176\end{array}$

$\begin{array}{llllll}(0.0101) & (0.0103) & (0.0105) & (0.0106) & (0.0106)\end{array}$

$\begin{array}{lllll}0.0512 & 0.0516 & 0.0505 & 0.0517 & 0.0513\end{array}$

$\begin{array}{llllll}(0.0111) & (0.0113) & (0.0113) & (0.0114) & (0.0114)\end{array}$

$\begin{array}{lllll}0.0669 & 0.0681 & 0.0692 & 0.0714 & 0.0707\end{array}$

$\begin{array}{llllll}(0.0237) & (0.0241) & (0.0243) & (0.0245) & (0.0245)\end{array}$

$\begin{array}{lllll}0.0412 & 0.0397 & 0.0393 & 0.0400 & 0.0402\end{array}$

$\begin{array}{llllll}(0.0083) & (0.0083) & (0.0083) & (0.0083) & (0.0083)\end{array}$

$\begin{array}{lllll}0.1057 & 0.1046 & 0.1055 & 0.1045 & 0.1042\end{array}$

$\begin{array}{llllll}(0.0241) & (0.0243) & (0.0245) & (0.0246) & (0.0246)\end{array}$

$\begin{array}{lllll}0.0845 & 0.0812 & 0.0788 & 0.0778 & 0.0772\end{array}$

$\begin{array}{llllll}(0.0180) & (0.0179) & (0.0179) & (0.0180) & (0.0179)\end{array}$

$\begin{array}{llllll}0.0239 & 0.0251 & 0.0251 & 0.0251 & 0.0248\end{array}$

$\begin{array}{llllll}(0.0076) & (0.0077) & (0.0077) & (0.0077) & (0.0077)\end{array}$

$\begin{array}{lllll}-0.0090 & -0.0089 & -0.0088 & -0.0088 & -0.0089\end{array}$

$\begin{array}{llllll}(0.0070) & (0.0070) & (0.0070) & (0.0071) & (0.0071)\end{array}$

$\begin{array}{lllll}-0.0200 & -0.0193 & -0.0193 & -0.0190 & -0.0192\end{array}$

$\begin{array}{llllll}(0.0079) & (0.0078) & (0.0079) & (0.0080) & (0.0080)\end{array}$

$\begin{array}{lllll}-0.0360 & -0.0348 & -0.0344 & -0.0340 & -0.0341\end{array}$

$\begin{array}{llllll}0.0089) & (0.0090) & (0.0091) & (0.0091) & (0.0091)\end{array}$

$\begin{array}{lllll}-0.0253 & -0.0255 & -0.0261 & -0.0259 & -0.0258\end{array}$

$\begin{array}{llllll}(0.0070) & (0.0070) & (0.0070) & (0.0071) & (0.0071)\end{array}$

$\begin{array}{lllll}-0.0189 & -0.0207 & -0.0209 & -0.0198 & -0.0197\end{array}$

$\begin{array}{lllll}(0.0090) & (0.0089) & (0.0090) & (0.0091) & (0.0091)\end{array}$

$\begin{array}{lllll}-0.0385 & -0.0400 & -0.0403 & -0.0397 & -0.0396\end{array}$

$\begin{array}{llllll}(0.0088) & (0.0087) & (0.0088) & (0.0089) & (0.0089)\end{array}$

$\begin{array}{lllll}-0.0149 & -0.0184 & -0.0188 & -0.0193 & -0.0193\end{array}$

$\begin{array}{lllll}(0.0080) & (0.0077) & (0.0077) & (0.0077) & (0.0077)\end{array}$

(continued) 
Table 8 (continued)

Probit Regressions for School Suspension

NLSY97

\begin{tabular}{|c|c|c|c|c|c|}
\hline \multirow[b]{2}{*}{ Explanatory variables } & \multicolumn{5}{|c|}{ Specification } \\
\hline & (1) & (2) & (3) & (4) & (5) \\
\hline \multirow[t]{2}{*}{ Household net worth $(10,000 \mathrm{~s})$} & -0.0005 & -0.0005 & -0.0005 & -0.0005 & -0.0005 \\
\hline & $(0.0004)$ & $(0.0004)$ & $(0.0004)$ & $(0.0004)$ & $(0.0004)$ \\
\hline \multirow[t]{2}{*}{ Household net worth squared $(10,000 s)$} & 0.0000 & 0.0000 & 0.0000 & 0.0000 & 0.0000 \\
\hline & $(0.0000)$ & $(0.0000)$ & $(0.0000)$ & $(0.0000)$ & $(0.0000)$ \\
\hline \multirow[t]{2}{*}{ Household income $(10,000 s)$} & -0.0001 & -0.0006 & -0.0007 & -0.0006 & -0.0005 \\
\hline & $(0.0022)$ & $(0.0022)$ & $(0.0022)$ & $(0.0022)$ & $(0.0022)$ \\
\hline \multirow[t]{2}{*}{ Household income squared $(10,000 s)$} & 0.0000 & 0.0000 & 0.0000 & 0.0000 & 0.0000 \\
\hline & $(0.0001)$ & $(0.0001)$ & $(0.0001)$ & $(0.0001)$ & $(0.0001)$ \\
\hline \multirow[t]{2}{*}{ Private school } & & 0.0258 & 0.0260 & 0.0264 & 0.0264 \\
\hline & & $(0.0105)$ & $(0.0106)$ & $(0.0107)$ & $(0.0107)$ \\
\hline \multirow[t]{2}{*}{ Other language spoken at home } & & & -0.0003 & 0.0019 & 0.0020 \\
\hline & & & $(0.0103)$ & $(0.0104)$ & $(0.0104)$ \\
\hline \multirow[t]{2}{*}{ Quiet place to study in household } & & & -0.0121 & -0.0124 & -0.0116 \\
\hline & & & $(0.0091)$ & $(0.0091)$ & $(0.0092)$ \\
\hline \multirow[t]{2}{*}{ Youth attends extra classes } & & & & -0.0060 & -0.0059 \\
\hline & & & & $(0.0061)$ & $(0.0061)$ \\
\hline \multirow[t]{2}{*}{ Dictionary present in household } & & & & & -0.0071 \\
\hline & & & & & $(0.0116)$ \\
\hline \multirow[t]{2}{*}{ Home computer } & -0.0279 & -0.0272 & -0.0272 & -0.0274 & -0.0272 \\
\hline & $(0.0058)$ & $(0.0058)$ & $(0.0058)$ & $(0.0058)$ & $(0.0059)$ \\
\hline Religion dummies & No & Yes & Yes & Yes & Yes \\
\hline Mean of dependent variable & 0.1132 & 0.1126 & 0.1131 & 0.1129 & 0.1130 \\
\hline Sample size & 17,326 & 17,081 & 16,926 & 16,806 & 16,794 \\
\hline
\end{tabular}

Notes: (1) See notes to Table 6. (2) Age dummy variables are also included in all specifications. (3) Robust standard errors that allow for correlated residuals over time are in parentheses. 
Table 9

Additional Regressions for School Suspension

NLSY97

Specification

\begin{tabular}{|c|c|c|c|c|c|}
\hline Explanatory variables & $(1)$ & $(2)$ & (3) & $(4)$ & (5) \\
\hline Home computer & $\begin{array}{c}-0.0090 \\
(0.0075)\end{array}$ & $\begin{array}{c}-0.0398 \\
(0.0085)\end{array}$ & $\begin{array}{l}-0.0384 \\
(0.0086)\end{array}$ & $\begin{array}{c}-0.0384 \\
(0.0086)\end{array}$ & $\begin{array}{c}-0.0384 \\
(0.0086)\end{array}$ \\
\hline Future home computer & & $\begin{array}{c}-0.0161 \\
(0.0077)\end{array}$ & $\begin{array}{c}-0.0151 \\
(0.0077)\end{array}$ & $\begin{array}{l}-0.0149 \\
(0.0078)\end{array}$ & $\begin{array}{c}-0.0155 \\
(0.0077)\end{array}$ \\
\hline Main controls & Time Varying & Yes & Yes & Yes & Yes \\
\hline Religion / private school & No & No & Yes & Yes & Yes \\
\hline Home environment & No & No & No & Yes & Yes \\
\hline Extra classes & No & No & No & No & Yes \\
\hline Fixed effects & Yes & No & No & No & No \\
\hline Mean of dependent variable & 0.1147 & 0.1263 & 0.1255 & 0.1255 & 0.1252 \\
\hline Sample size & 17,751 & 13,432 & 13,238 & 13,221 & 13,127 \\
\hline
\end{tabular}

Note: See notes to Table 8. 
Table 10

Regressions for Criminal Activity

NLSY97

(1)

(2)

(3)

(4)

\begin{tabular}{|c|c|c|c|c|}
\hline \multicolumn{5}{|l|}{ Any criminal activity } \\
\hline Home computer & $\begin{array}{l}-0.0120 \\
(0.0088)\end{array}$ & $\begin{array}{c}-0.0113 \\
(0.0088)\end{array}$ & $\begin{array}{c}0.0001 \\
(0.0090)\end{array}$ & $\begin{array}{c}-0.0074 \\
(0.0132)\end{array}$ \\
\hline Dictionary present in household & & $\begin{array}{c}-0.0154 \\
(0.0197)\end{array}$ & & \\
\hline Future home computer & & & & $\begin{array}{c}0.0078 \\
(0.0137)\end{array}$ \\
\hline Fixed effects & No & No & Yes & No \\
\hline Mean of dependent variable & 0.2449 & 0.2448 & 0.2342 & 0.2641 \\
\hline Sample size & 18,192 & 18,178 & 21,909 & 13,355 \\
\hline \multicolumn{5}{|l|}{ Arrests } \\
\hline Home computer & $\begin{array}{c}-0.0179 \\
(0.0041)\end{array}$ & $\begin{array}{c}-0.0176 \\
(0.0042)\end{array}$ & $\begin{array}{l}-0.0080 \\
(0.0055)\end{array}$ & $\begin{array}{c}-0.0146 \\
(0.0055)\end{array}$ \\
\hline Dictionary present in household & & $\begin{array}{c}-0.0036 \\
(0.0079)\end{array}$ & & \\
\hline Future home computer & & & & $\begin{array}{c}0.0023 \\
(0.0055)\end{array}$ \\
\hline Fixed effects & No & No & Yes & No \\
\hline Mean of dependent variable & 0.0597 & 0.0595 & 0.0604 & 0.0597 \\
\hline Sample size & 18,178 & 18,164 & 21,895 & 13,300 \\
\hline \multicolumn{5}{|l|}{ Gang activity } \\
\hline Home computer & $\begin{array}{l}-0.0020 \\
(0.0013)\end{array}$ & $\begin{array}{l}-0.0019 \\
(0.0012)\end{array}$ & $\begin{array}{c}-0.0022 \\
(0.0031)\end{array}$ & $\begin{array}{l}-0.0028 \\
(0.0021)\end{array}$ \\
\hline Dictionary present in household & & $\begin{array}{c}-0.0028 \\
(0.0024)\end{array}$ & & \\
\hline Future home computer & & & & $\begin{array}{c}0.0002 \\
(0.0016)\end{array}$ \\
\hline Fixed effects & No & No & Yes & No \\
\hline Mean of dependent variable & 0.0211 & 0.0209 & 0.0200 & 0.0237 \\
\hline Sample size & 18,240 & 18,226 & 21,966 & 13,380 \\
\hline
\end{tabular}

Note: See notes to Table 8. 